\title{
Partitioning of Organic Ions to Muscle Protein: Experimental Data, Modeling, and Implications for in Vivo Distribution of Organic Ions
}

\section{Luise Henneberger, Kai-Uwe Goss, and Satoshi Endo}

\begin{tabular}{|c|l|}
\hline Citation & Environmental Science \& Technology, 50(13); 7029-7036 \\
\hline Issue Date & 2016-6-06 \\
\hline Type & Journal Article \\
\hline Textversion & author \\
\hline Right & $\begin{array}{l}\text { This document is the Accepted Manuscript version of a Published Work that appeared in } \\
\text { final form in Environmental Science \& Technology, copyright @ American Chemical Society } \\
\text { after peer review and technical editing by the publisher. To access the final edited and } \\
\text { published work see https://doi.org/10.1021/acs.est.6b01417 }\end{array}$ \\
\hline URI & http://dlisv03.media.osaka-cu.ac.jp/il/meta_pub/G0000438repository_15205851-50-13-7029 \\
\hline DOI & 10.1021/acs.est.7b05144 \\
\hline
\end{tabular}

SURE: Osaka City University Repository http://dlisv03.media.osaka-cu.ac.jp/il/meta_pub/G0000438repository

HENNEBERGER, L., GOSS, K.-U., \& ENDO, S. (2016). Partitioning of Organic Ions to Muscle Protein: Experimental Data, Modeling, and Implications for in Vivo Distribution of Organic Ions. Environmental Science \& Technology. 50, 7029-7036. 


\section{Partitioning of Organic Ions to Muscle Protein:}

$5 \dagger \dagger$ Helmholtz Centre for Environmental Research UFZ, Permoserstr. 15, D-04318 Leipzig,

\$ University of Halle-Wittenberg, Institute of Chemistry, Kurt-Mothes-Str. 2, D-06120 Halle,

\section{ABSTRACT}

12 The in vivo partitioning behavior of ionogenic organic chemicals (IOCs) is of paramount

13 importance for their toxicokinetics and bioaccumulation. Among other proteins, structural

14 proteins including muscle proteins could be an important sorption phase for IOCs, because of

15 their high quantity in the human and other animals' body and their polar nature. Binding data for

16 IOCs to structural proteins are, however, severely limited. Therefore, in this study muscle 
17 protein-water partition coefficients $\left(K_{\mathrm{MP} / \mathrm{w}}\right)$ of 51 systematically selected organic anions and

18 cations were determined experimentally. A comparison of the measured $K_{\mathrm{MP} / \mathrm{w}}$ with bovine

19 serum albumin (BSA)-water partition coefficients showed that anionic chemicals sorb stronger to

20 BSA than to muscle protein (up to 3.5 orders of magnitude), while cations sorb similarly to both

21 proteins. Sorption isotherms of selected IOCs to muscle protein are linear (i.e., $K_{\mathrm{MP} / \mathrm{w}}$ is

22 concentration independent) and $K_{\mathrm{MP} / \mathrm{w}}$ is only marginally influenced by $\mathrm{pH}$ value and salt

23 concentration. Using the obtained dataset of $K_{\mathrm{MP} / \mathrm{w}}$ a polyparameter linear free energy

24 relationship (PP-LFER) model was established. The derived equation fits the data well $\left(R^{2}=0.89\right.$,

25 RMSE $=0.29$ ). Finally, it was demonstrated that the in vitro measured $K_{\mathrm{MP} / \mathrm{w}}$ of this study have

26 the potential to be used to evaluate tissue-plasma partitioning of IOCs in vivo.

\section{Introduction}

29 Assessing the toxicity and the bioaccumulation potential of chemicals in the environment 30 requires reliable information on their partitioning into biological compartments such as lipids and

31 proteins. In the past, environmental scientists mainly focused on neutral organic chemicals and

32 predictive tools with different levels of complexity have been developed for these chemicals. In

33 simple models it is often assumed that the predominant sorption phase is the lipid fraction of an

34 organism and that octanol is an appropriate surrogate for lipids. Models with more mechanistic

35 insight explicitly consider different types of lipids and proteins as sorbing phases ${ }^{1-3}$ and/or use

36 more sophisticated approaches to predict relevant partition coefficients. For example

37 polyparameter linear free energy relationships (PP-LFERs) ${ }^{4,5}$ have been established for different

38 biological phases including storage lipid, ${ }^{6}$ phospholipids, ${ }^{7}$ and proteins. ${ }^{8,9}$ 
Although there is a need for predictive models that are capable of predicting the toxicity and

40 the bioaccumulation potential of ionogenic organic chemicals (IOCs) as well, only a few

41 attempts have been made so far to include IOCs in environmental partitioning models. ${ }^{10}$ For a

42 better understanding of bio-partitioning of IOCs, the relevant sorption phases for organic ions

43 have to be identified. In contrast to neutral chemicals, IOCs are not expected to primarily

44 partition to storage lipid, but rather to polar lipids (phospholipid membranes) and proteins.

45 At least two classes of protein may serve as significant sorption phases for IOCs in vivo. First,

46 serum albumin and other serum proteins: Serum albumin is well-known for its ability to bind a

47 broad range of chemicals, especially organic anions, reducing their freely dissolved fraction in

48 plasma and increasing the sorption capacity of the plasma. ${ }^{11,12}$ Additionally, for cationic and

49 neutral chemicals a significant contribution of another plasma protein ( $\alpha 1$-acid glycoprotein) to

50 the sorption capacity of the plasma has also been described. ${ }^{13}$ In our previous study with bovine

51 serum albumin (BSA), we measured serum albumin binding for a set of systematically selected

52 organic anions and cations, in order to reveal the mechanisms that underlie the partitioning. ${ }^{14} \mathrm{We}$

53 pointed out the influence of the molecular structure, especially the three-dimensional (3D) shape,

54 on the sorption of organic ions to BSA and discussed the requirements for successful modeling

55 of serum albumin binding of IOCs. ${ }^{14}$

56 The second class of proteins that could be an important sorption phase for IOCs are structural

57 proteins. Structural proteins make up the majority of the proteins in the human body, with a

58 fraction of $10 \%$ by mass of the whole body. About half of the structural proteins $(4 \%$ of the

59 whole body mass) are muscle proteins (e.g., actin and myosin). The other half (6\% of the whole

60 body mass) include keratin and collagen. ${ }^{15,16}$ Generally, structural proteins are not expected to

61 be a target site for toxic actions, but similar to serum albumin, sorption to structural protein can 
62 be substantial and affect the transport, distribution, and freely dissolved concentration of

63 chemicals in the body. There are studies that focused on the sorption of organic chemicals to

64 different structural proteins (i.e., gelatin, muscle protein, collagen, and keratin), ${ }^{9,17-19}$ but their

65 targets were mainly neutral organic chemicals. Only a few studies have included some binding

66 data for IOCs as well. ${ }^{18,19}$

67 Because for many chemicals partitioning data for proteins other than serum albumin are not 68 readily available, partitioning models often consider the bulk protein fraction of an organism as

69 one sorption phase, using serum albumin as a representative protein for all proteins. ${ }^{2}$ Endo et al.

70 have shown in their study that for neutral chemicals, sorption to muscle protein and serum

71 albumin is profoundly different. ${ }^{9}$ This difference is reasonable, because sorption to serum

72 albumin generally happens at specific binding sites, ${ }^{9,11,20}$ while this is presumably not the case

73 for structural proteins. A further study demonstrated that structural proteins can be a more

74 important sorption phase than lipids for H-bond donor neutral chemicals in lean tissues. ${ }^{1}$ Such

75 general conclusions could not be made for IOCs so far, because data for binding of IOCs to

76 structural proteins are rare.

77 As an extension of our previous work with serum albumin, ${ }^{14}$ the aim of this study was to

78 investigate how the molecular structure of IOCs influences their sorption to structural protein

79 and to elucidate the sorption mechanism. For this purpose, muscle protein isolated from chicken

80 breast filet was used as a model protein and muscle protein-water partition coefficients $\left(K_{\mathrm{MP} / \mathrm{w}}\right)$

81 were determined for organic anions and cations with diverse molecular structure (e.g., with

82 different charged functional groups and basic structure) using an equilibrium dialysis method.

83 Because partitioning processes of ions are potentially influenced by $\mathrm{pH}$ value and salt

84 concentration, the dependence of $\log K_{\mathrm{MP} / \mathrm{w}}$ on $\mathrm{pH}$ value and the concentration of other inorganic 
85 (phosphate and $\mathrm{K}^{+}$) and organic ions (lactate) were investigated for selected test chemicals.

86 Furthermore, sorption isotherms were measured and the reversibility of binding to muscle

87 protein was checked. Using the obtained dataset for muscle protein binding of IOCs,

88 polyparameter linear free energy relationships (PP-LFERs) were tested for their suitability as a

89 predictive tool. The measured $\log K_{\mathrm{MP} / \mathrm{w}}$ values were also compared with serum albumin-water

90 partition coefficients from our previous study. Finally, we evaluated how far partitioning to

91 serum albumin and structural protein can explain muscle tissue-plasma partition coefficients that

92 were measured in vivo.

93 Materials and methods

\section{Materials}

95 Muscle proteins were isolated from chicken breast filet as described by Endo et al. ${ }^{9}$ (for details

96 on protein preparation and lipid extraction, see the supporting information (SI)). The protein

97 content of typical muscle-meat is approximately $19 \%$ according to ref 21 . Because the amount of

98 muscle protein required for the experiments was larger than originally expected, two lots of

99 protein had to be prepared. The two lots sometimes exhibited slightly different $K_{\mathrm{MP} / \mathrm{w}}$ by up to

$1000.2 \log$ units, but without any clear trend. That is, three out of seven chemicals for which a

101 comparison is possible showed lot $2>\operatorname{lot} 1$ and the remaining four chemicals $\operatorname{lot} 1>\operatorname{lot} 2$. Thus,

102 we assumed that the lot difference in terms of sorption properties is negligible and, therefore,

103 combined data measured with the two lots. Table S1 in SI shows which lot was used for each

104 experiment. The water used for the experiments was purified with a Milli-Q Gradient A10

105 system from Millipore. Methanol (Suprasolv) and acetonitrile (gradient grade) were acquired

106 from Merck and Sigma Aldrich, respectively. Lactic acid, $\mathrm{NaN}_{3}, \mathrm{KH}_{2} \mathrm{PO}_{4}$ and $\mathrm{K}_{2} \mathrm{HPO}_{4} \cdot 3 \mathrm{H}_{2} \mathrm{O}$

107 were purchased from Merck or Sigma Aldrich. The test chemicals chosen for the experiments 
108 with muscle protein were various organic anions and cations. In particular, differently substituted 109 benzoic acids, naphthoic acids, and sulfonates were chosen to elucidate the influence of the 110 molecular structure on the sorption to muscle protein. Several pesticides and pharmaceuticals 111 were added to the dataset, because of their environmental relevance. We especially considered 112 the chemicals from our previous work with $\mathrm{BSA}^{14}$ to ensure a good overlap of the datasets for 113 the two proteins. All test chemicals measured in this study have only one ionizable functional 114 group and are predominantly present as their ionic species at $\mathrm{pH} 7.0(>97 \%)$. Note that the term 115 "ionogenic organic chemical" (IOC) could refer to weak acids and bases that are primarily 116 neutral as well, but within this study IOCs only mean chemicals that are mainly present as their 117 ionic species in an aqueous phase at physiological $\mathrm{pH}$ values. Although all data reported here are

118 for ionic species, the chemical names of neutral species are often used for acids and bases (e.g.,

119 3-chlorobenzoic acid instead of 3-chlorobenzoate), because they are more common. Additional 120 information on the test chemicals (e.g. CAS number, provider, chemical structure, $\mathrm{p} K_{\mathrm{a}}$ values 121 and recovery from control experiments) is summarized in Table S2, SI. Unless otherwise 122 specified below, all dialysis experiments were conducted using $30 \mathrm{mM}$ phosphate buffer at $\mathrm{pH}$ 123 7.7, which gave the targeted $\mathrm{pH}$ of 7.0-7.1 in the presence of the muscle protein sample (more 124 details on the dialysis experiments and on the choice of buffer are provided in the SI). 125 Controlling the ion composition and $\mathrm{pH}$ value of the buffer in the dialysis experiments was found 126 to be difficult, because salts and acids (particularly lactic acid) from the muscle protein sample 127 were found to contribute significantly to the salt concentration and the $\mathrm{pH}$ value of the buffer. 128 Therefore, the actual salt composition and $\mathrm{pH}$ value in the solution after dialysis experiments 129 were determined (Table 1). The change in $\mathrm{pH}$ and salt concentrations upon addition of muscle 130 protein could be avoided in future experiments by an additional purification step, for example by 
131 dialyzing the protein against a large amount of buffer solution. To prevent microbial growth all

132 solutions contained $300 \mathrm{mg} / \mathrm{L} \mathrm{NaN}_{3}$ (i.e. $4.6 \mathrm{mM} \mathrm{NaN}_{3}$ ).

133 Table 1. Measured salt concentrations and $\mathrm{pH}$ value of buffer solution used for the dialysis

134 experiments with muscle protein. All values are from a single measurement (except for

135 phosphate, for which the mean of 2 measurements is shown); $\mathrm{pH}$ value was checked regularly

136 after dialysis and was always within $\pm 0.1 \log$ unit.

\begin{tabular}{|c|c|c|c|c|}
\hline Analyte & $\begin{array}{c}\text { Buffer before } \\
\text { dialysis } \\
\mathrm{c}[\mathrm{mmol} / \mathrm{L}] \\
\end{array}$ & $\begin{array}{c}\text { Buffer after } \\
\text { dialysis }^{\mathbf{a}, \mathbf{b}} \\
\mathrm{c}[\mathrm{mmol} / \mathrm{L}]\end{array}$ & $\begin{array}{c}\text { Buffer after } \\
\text { dialysis }^{\mathrm{a}, \mathrm{c}} \\
\mathrm{c}[\mathrm{mmol} / \mathrm{L}]\end{array}$ & $\begin{array}{c}\text { Intracellular } \\
\text { concentration }^{d} \\
\mathrm{c}[\mathrm{mmol} / \mathrm{L}]\end{array}$ \\
\hline Chloride & n.a. & 1.8 & 2.0 & $5-15$ \\
\hline Phosphate & 34 & 44 & 39 & - \\
\hline Lactate & n.a. & 14 & 9.7 & - \\
\hline $\mathrm{Ca}$ & n.a. & 0.1 & 0.1 & $10^{-4}$ \\
\hline $\mathrm{Fe}$ & n.a. & $1.3 \times 10^{-3}$ & $1.0 \times 10^{-3}$ & - \\
\hline $\mathrm{K}$ & 47 & 67 & 61 & 140 \\
\hline $\mathrm{Na}$ & 8.9 & 6.6 & 6.7 & $5-15$ \\
\hline $\mathrm{Mg}$ & n.a. & 2.2 & 1.7 & 0.5 \\
\hline $\mathrm{pH}$ & 7.7 & 7.0 & 7.1 & 7.1 \\
\hline \multicolumn{5}{|c|}{ a amount of muscle protein: $500 \mathrm{mg} / 10 \mathrm{~mL}$ buffer } \\
\hline \multicolumn{5}{|c|}{${ }^{b}$ first lot of muscle protein } \\
\hline \multicolumn{5}{|c|}{${ }^{\mathrm{c}}$ second lot of muscle protein } \\
\hline \multicolumn{5}{|c|}{${ }^{\mathrm{d}}$ from ref 22} \\
\hline n.a. not & ed & & & \\
\hline
\end{tabular}

137 Dialysis experiments

138 An equilibrium dialysis approach was chosen to determine the extent of binding to muscle

139 protein, expressed as muscle protein-water partition coefficient $\left(\log K_{\mathrm{MP} / \mathrm{w}}\right)$. Log $K_{\mathrm{MP} / \mathrm{w}}$ is defined

140 as the ratio of the concentration of the target chemical in muscle protein $\left(C_{\mathrm{MP}}\right)$ to the freely

141 dissolved concentration in water $\left(C_{\text {free }}\right)$ :

$$
K_{M P / w}\left[\frac{L_{\text {water }}}{k g_{M P}}\right]=\frac{C_{M P}}{C_{\text {free }}}
$$


143 The experimental setup for the dialysis experiments was similar to that in our previous studies

144 with BSA, ${ }^{14,23}$ where buffer solutions with and without protein were separated with dialysis

145 membrane and the concentration of the chemical in the buffer-only solution $\left(=C_{\text {free }}\right)$ was

146 measured after equilibration (see SI for more details). The main difference between BSA and

147 muscle protein in the experiments was the solubility in water. Unlike serum albumin the muscle

148 protein did not completely dissolve in water. Therefore, instead of pipetting a protein solution

149 into the dialysis cells, a fixed amount of muscle protein was directly weighed into one half cell of

150 the dialysis cells and $5 \mathrm{~mL}$ of a diluted solution of the test chemical in buffer were added. For all

151 test chemicals 3-4 replicates of the muscle protein cells were prepared and additionally 3-4

152 control samples without protein. The recovery of the test chemicals from the control samples was

153 on average $87-105 \%$. Because of the high amount of undissolved protein, stirring of the muscle

154 protein suspension in the dialysis cells was not possible. Instead, the cells were equilibrated on

155 an orbital shaker at $200 \mathrm{rpm}$ at $37^{\circ} \mathrm{C}$. As with our experiments with BSA, concentration

156 measurements were always performed after 48 and 72 hours, indicating no difference (data not

157 shown). Hence, data for both time points were combined and used to calculate the mean. The

158 same amount of muscle protein $(500 \mathrm{mg})$ was used for all experiments, because the final salt

159 composition of the medium was found to be dependent on the amount of muscle protein (see also

160 Table 1). SpectralPor 3 dialysis membrane from Spectrum Laboratories was used (for more

161 information on the membrane and quantification of leaking, see SI).

\section{Reversibility of binding to muscle protein}

163 Because irreversible binding of the test chemicals to muscle protein would complicate the

$164 K_{\mathrm{MP} / \mathrm{w}}$ measurement, reversibility of muscle protein binding was determined using the method

165 described in our previous work with BSA. ${ }^{14}$ In short: muscle protein samples were prepared as

166 described above and the dialysis experiment was performed. After three-day equilibration, the 
167 buffer containing half-cell was emptied completely and was refilled with fresh buffer. A small

168 shift in $\mathrm{pH}$ (from 7.0 to 7.3 ) was observed upon addition of fresh buffer in the first reversibility

169 tests (with anionic chemicals) and we improved the experimental setup for the cationic chemicals

170 by adding $10 \mathrm{mM}$ lactate to the refill buffer (i.e., making the buffer more similar to the dialysate).

171 Additional three days were given for equilibration and the buffer phase was sampled again. If

172 binding to muscle protein is completely reversible and no mass loss of the chemicals occurred,

173 the partition coefficients calculated from the equilibrium concentrations measured after three and

174 six days should be the same. If a test chemical is irreversibly bound to muscle protein or

175 degraded in the presence of protein, $\log K_{\mathrm{MP} / \mathrm{w}}$ determined after six days should become higher

176 than after three days.

\section{Isotherm experiments}

178 Because $\log K_{\mathrm{MP} / \mathrm{w}}$ for the test chemicals of this study were measured at different concentration

179 levels, it is important for their comparability that the sorption to muscle protein is linear (i.e.,

$180 K_{\mathrm{MP} / \mathrm{w}}$ is independent of the concentration of the chemical) or that the degree of non-linearity is

181 known. Linearity of sorption was checked for five anionic (2-naphthoic acid, 3,4-

182 dichlorobenzoic acid, 4-butylbenzoic acid, ketoprofen, and 2,3,5,6-tetrachlorophenol) and one

183 cationic test chemical ((S)-(-)-propranolol). Dialysis cells were prepared as described above, 3-5

184 concentration levels were measured for each chemical and the initial concentrations of the

185 respective test chemicals was varied by 1.5 to 3.5 orders of magnitude.

\section{Influence of $\mathbf{p H}$ value, lactate and salt concentration}

187 The partitioning of organic ions to proteins can be influenced by $\mathrm{pH}$ value and salt

188 concentration. Previous studies with serum albumin found no clear trend in $\mathrm{pH}$ dependence ${ }^{14,24}$

189 but a significant competing effect of chloride on the partitioning of organic anions. ${ }^{14,25,26}$ For log

$190 K_{\mathrm{MP} / \mathrm{w}}$ the dependence on $\mathrm{pH}$ value and the influence of the concentration of other ions has not 
191 been investigated so far. Therefore, $\log K_{\mathrm{MP} / \mathrm{w}}$ of 3,4-dichlorobenzoic acid and

192 benzyldimethyloctylammonium were measured in $30 \mathrm{mM}$ phosphate buffer adjusted to $\mathrm{pH} 6,8$

193 and 9 (at equilibrium with muscle protein) in addition to our regular solution with $\mathrm{pH}$ 7. The

194 partitioning of 3,4-dichlorobenzoic acid, coumachlor, and benzyldimethyloctylammonium to

195 muscle protein was also measured at two additional concentrations of $\mathrm{K}^{+}$and phosphate $(8$ and

$196105 \mathrm{mM}$ phosphate, corresponding to 16 and $157 \mathrm{mM} \mathrm{K}^{+}$, respectively, measured at equilibrium),

197 while $\mathrm{pH}$ was kept between 6.5 and 7.1 at equilibrium.

198 The isolated muscle protein used for this study contained considerable amounts of lactic acid.

199 Because the lactate concentration in our test system after equilibration with muscle protein was

200 higher than the concentration of lactate in muscle in vivo (for calculation see SI), we also

201 investigated the influence of lactate on $\log K_{\mathrm{MP} / \mathrm{w}}$. For this purpose sorption of 3,4-

202 dichlorobenzoic acid, coumachlor and benzyldimethyloctylammonium was additionally

203 measured at equilibrium lactate concentrations of 42 and $96 \mathrm{mM}$ (final $\mathrm{pH}$ adjusted to 7.0 with

$204 \mathrm{KOH})$.

205 Instrumental analysis

206 All test chemicals were measured with an HPLC system from JASCO, equipped with either a

207 UV detector (UV-970 M, JASCO) or a fluorescence detector (RF-10AXL, Shimadzu).

208 Depending on the chemicals, either an Eclipse Plus C18 column $(4.6 \mathrm{~mm} \times 100 \mathrm{~mm}, 5 \mu \mathrm{m}$

209 particle size) or a ZORBAX Extend C18 column $(4.6 \mathrm{~mm} \times 150 \mathrm{~mm}, 5 \mu \mathrm{m}$ particle size $)$, both

210 from Agilent, was used. The eluent was a mixture of acetonitrile and water (both containing 0.1

$211 \mathrm{wt} \%$ orthophosphoric acid) at a flow rate of $1 \mathrm{~mL} / \mathrm{min}$. For four anionic (3-chlorobenzoic acid,

212 3-methoxy-2-naphthoic acid, 2,4,6-trimethylbenzene sulfonate and 4-bromobenzene sulfonate)

213 and three cationic test chemicals (verapamil, difenzoquat and dibenzylamine) the influence of the 
214 dissolved small molecules from the protein sample on the quantification was checked.

215 Calibration standards prepared in clean phosphate buffer (for cations, phosphate buffer with

216 lactate) and in buffer that was dialyzed against muscle protein were measured and compared. No

217 difference between the two sets of standards was found, indicating that the components in the 218 dialysate did not interfere with the quantification of the test chemicals in the dialysis experiments.

\section{Results and discussion}

\section{Reversibility tests}

221 The results from the reversibility tests are presented in Table S3, SI. Interestingly, $\log K_{\mathrm{MP} / \mathrm{w}}$

222 determined from samples taken at day six are slightly smaller than $\log K_{\mathrm{MP} / \mathrm{w}}$ determined for day

223 three (on average $0.09 \log$ units). Since irreversible binding or a mass loss should result in a

224 higher $K_{\mathrm{MP} / \mathrm{w}}$ on day six than on day three, binding to muscle protein seems to be reversible for

225 the eleven chemicals tested. While the cause of the difference between $\log K_{\mathrm{MP} / \mathrm{w}}$ determined on 226 days three and six is unknown, several explanations may be conceivable. First, salt

227 concentrations are slightly different between days three and six, because the composition of fresh

228 buffer added after three days is not the same as that of the dialysate removed (see also Table 1).

229 For the anionic test chemicals, a small shift in $\mathrm{pH}$ (from 7.0 to 7.3 ) was also measured (see

230 method section). However, small shifts in $\mathrm{pH}$ and salt composition should not have a significant

231 influence on $\log K_{\mathrm{MP} / \mathrm{w}}$ (see next section). Second, a volume shift due to the osmotic pressure

232 caused by muscle protein is possible, but was found to be small (only up to $10 \%$ of the total

233 volume). Third, because of the prolonged duration of the experiment, the muscle protein might

234 have partly degraded or structurally reorganized. In any case, the differences observed were 235 small and do not have an influence on the following discussions. 

increases $0.4 \log$ units. This small change in the partitioning behavior with $\mathrm{pH}$ could be explained by assuming that the protein carries more positive net charges at lower $\mathrm{pH}$ (attractive for 3,4-dichlorobenzoic acid) and more negative net charges at higher $\mathrm{pH}$ (attractive for benzyldimethyloctylammonium), yet actual sorption mechanisms are unknown.

Muscle protein binding of 3,4-dichlorobenzoic acid, coumachlor and benzyldimethyloctylammonium was measured at different concentrations of $\mathrm{K}^{+}$, phosphate and lactate (Figure S2, SI). The concentration of other organic or inorganic ions was expected to influence the sorption of the test chemicals to muscle protein for various possible reasons such as competition for possible binding sites for ions and ion pair formation. However, a factor of $\mathbf{1 0}$ difference in the $\mathrm{K}^{+}$, phosphate or lactate concentration caused only a factor of $\leq 1.6$ difference in $K_{\mathrm{MP} / \mathrm{w}}$ (or $\leq 0.2 \mathrm{log}$ units) for the three chemicals tested, indicating no substantial influence of salt concentrations on the sorption. From these results it can be concluded that it is unlikely an ion exchange process or ion pair partitioning that dominates the partitioning of organic ions to muscle protein. The results indicate that minor variations in experimental $\mathrm{pH}$ and salt concentrations do not influence $K_{\mathrm{MP} / \mathrm{w}}$. Nevertheless, some control is still needed, because shifts in $\mathrm{pH}$ value can change the 258 speciation of ionizable chemicals, and neutral and ionic species of a chemical 259 can exhibit different partitioning behavior toward the protein. In future 260 experiments this is especially important for chemicals with a $\mathrm{p} K_{\mathrm{a}}$ value close 261 to 7, for which ionic and neutral species are present in equal 262 distribution.Sorption isotherms

263 Sorption isotherms were measured for six test chemicals (2-naphthoic acid, 3,4-

264 dichlorobenzoic acid, 4-butylbenzoic acid, ketoprofen, 2,3,5,6-tetrachlorophenol and (S)-(-)-

265 propranolol). All isotherms were fitted using the log-transformed Freundlich model, $\log C_{\mathrm{MP}}=n_{\mathrm{f}}$

$266 \cdot \log C_{\text {free }}+\log K_{\mathrm{Fr}}$, where $n_{\mathrm{f}}$ and $K_{\mathrm{Fr}}$ are the Freundlich exponent and Freundlich coefficient,

267 respectively. The Freundlich exponent is $1.00 \pm 0.08$ (mean \pm standard deviation) for the tested 
268 chemicals, indicating linear sorption to muscle protein (Figure S4, SI). We, therefore, surmise

269 that $\log K_{\mathrm{MP} / \mathrm{w}}$ measured at a single concentration (Table 2) can represent the sorption behavior of

270 the test chemicals at different concentrations.

271 Table 2. Determined logarithmic muscle protein-water partition coefficients $\left(\log K_{\mathrm{MP} / \mathrm{w}}\right)$ at $37^{\circ} \mathrm{C}$,

272 final $\mathrm{pH}$ 7.0-7.1 and final salt concentration as stated in Table 1. Log $K_{\mathrm{MP} / \mathrm{w}}$ was calculated based

273 on the dry weight of muscle protein. The concentration of muscle protein in the experiments was

274 always $5 \%$ by weight.

\begin{tabular}{|c|c|c|}
\hline Test chemical & $\begin{array}{c}\log K_{M P / w} \\
{[\text { Lwater/kgMP] }}\end{array}$ & SD \\
\hline \multicolumn{3}{|l|}{ Benzoic acids } \\
\hline 3-chlorobenzoic acid & 0.72 & 0.02 \\
\hline 4-chlorobenzoic acid & 0.72 & 0.03 \\
\hline 3,4-dichlorobenzoic acid & 1.31 & 0.02 \\
\hline 4-bromobenzoic acid & 0.91 & 0.01 \\
\hline 4-butylbenzoic acid & 1.39 & 0.01 \\
\hline 4-hexylbenzoic acid & 2.17 & 0.04 \\
\hline 2-cyclohexylbenzoic acid & 1.14 & 0.02 \\
\hline \multicolumn{3}{|l|}{ Naphthoic acids } \\
\hline 2-naphthoic acid & 1.14 & 0.01 \\
\hline 2-naphthaleneacetic acid & 1.09 & 0.02 \\
\hline 1-naphthoic acid & 0.87 & 0.02 \\
\hline 1-naphthaleneacetic acid & 0.98 & 0.02 \\
\hline 4-fluoro-1-naphthoic acid & 1.00 & 0.02 \\
\hline 1-bromo-2-naphthoic acid & 1.19 & 0.02 \\
\hline 6-bromo-2-naphthoic acid & 1.89 & 0.02 \\
\hline 2-methoxy-1-naphthoic acid & 0.70 & 0.01 \\
\hline 2-ethoxy-1-naphthoic acid & 0.74 & 0.02 \\
\hline 3-methoxy-2-naphthoic acid & 0.85 & 0.02 \\
\hline \multicolumn{3}{|l|}{ Phenoxy acids } \\
\hline 4-(2,4-dichlorophenoxy)butyric acid & 1.53 & 0.01 \\
\hline 2,4,5-trichlorophenoxyacetic acid & 1.61 & 0.03 \\
\hline mecoprop ${ }^{\mathrm{a}}$ & 1.17 & 0.02 \\
\hline \multicolumn{3}{|l|}{ Arylpropionic acids } \\
\hline ketoprofen ${ }^{\mathrm{a}}$ & 1.21 & 0.02 \\
\hline ibuprofen ${ }^{\mathrm{a}}$ & 1.48 & 0.04 \\
\hline fenoprofen ${ }^{a}$ & 1.62 & 0.03 \\
\hline
\end{tabular}


(S)-(+)-naproxen

$1.33 \quad 0.02$

Anthranilic acid derivatives

N-phenylanthranilic acid

$\begin{array}{ll}1.86 & 0.04\end{array}$

flufenamic acid

$2.40 \quad 0.07$

mefenamic acid

$2.40 \quad 0.02$

Phenols

2,3,5,6-tetrachlorophenol

$\begin{array}{ll}2.63 & 0.02\end{array}$

pentachlorophenol

$3.36 \quad 0.20$

dinoseb $^{\mathrm{a}}$

$2.45 \quad 0.02$

dinoterb

$2.46 \quad 0.04$

bromoxynil

$1.74 \quad 0.02$

Coumarines

coumachlor

$2.21^{\mathrm{b}} \quad 0.02$

coumafuryl

$1.14 \quad 0.07$

Others

diclofenac

$\begin{array}{ll}2.47 & 0.08\end{array}$

1-pyrenecarboxylic acid $\quad 2.30^{\mathrm{b}} \quad 0.02$

Sulfonates

4-n-octylbenzenesulfonate

$2.81^{\mathrm{b}} \quad 0.04$

2,4,6-trimethylbenzenesulfonate $\quad 0.72^{\mathrm{b}} \quad 0.02$

4-bromobenzenesulfonate $\quad 0.86^{\mathrm{b}} \quad 0.04$

naphthalene-2-sulfonate $\quad 1.03^{\mathrm{b}} \quad 0.05$

$\begin{array}{lll}\text { 1-pyrene sulfonate } & 2.40^{\mathrm{b}} & 0.03\end{array}$

Cations

$\begin{array}{lll}\text { (S)-(-)-propranolol } & 1.48^{\mathrm{b}} & 0.02\end{array}$

$\begin{array}{lll}\text { alprenolol }^{\mathrm{a}} & 1.17^{\mathrm{b}} & 0.06\end{array}$

$\begin{array}{lll}\text { fluoxetine }^{\mathrm{a}} & 2.04^{\mathrm{b}} & 0.01\end{array}$

dibenzylamine $\quad 1.29^{\mathrm{b}} \quad 0.02$

imipramine $\quad 1.83^{\mathrm{b}} \quad 0.03$

$\begin{array}{lll}\text { verapamil }^{\mathrm{a}} & 1.54^{\mathrm{b}} & 0.07\end{array}$

$\begin{array}{lll}\text { difenzoquat } & 0.92^{\mathrm{b}} & 0.07\end{array}$

benzyltributylammonium $\quad 0.89^{\mathrm{b}} \quad 0.09$

benzyldimethyloctylammonium $\quad 1.44^{\mathrm{b}} \quad 0.02$

\begin{tabular}{lll} 
tetraphenylphosphonium & $1.80^{\mathrm{b}}$ & 0.01 \\
\hline
\end{tabular}

a Chiral compounds. Because no information on the enantiomeric composition was available, we assumed the racemic mixture.

${ }^{\mathrm{b}}$ Determined using the second lot of muscle protein.

\section{Muscle protein-water partition coefficients}


276 Muscle protein-water partition coefficients $\left(\log K_{\mathrm{MP} / \mathrm{w}}\right)$ were determined for 41 anionic and 10

277 cationic chemicals on a single concentration level (Table 2). Compared to the previously 278 determined partition coefficients to BSA, the measured partition coefficients of this study are 279 rather low. For the majority of the test chemicals (38 out of 51) $\log K_{\mathrm{MP} / \mathrm{w}}$ is smaller than 2 and 280 many chemicals could not be measured because of too weak sorption (fraction bound $<20 \%$, 281 which corresponds to $\log K_{\mathrm{MP} / \mathrm{w}} \leq 0.6$; Table S4, SI). Two primary amines (4-phenylbutylamine 282 and 1-naphthylmethylamine) had to be removed from the dataset, because results for $\log K_{\mathrm{MP} / \mathrm{w}}$ 283 were not reproducible.

284 Especially compared to the BSA-water partition coefficients $\left(\log K_{\mathrm{BSA} / \mathrm{w}}\right)$ measured in our 285 previous study, ${ }^{14} \log K_{\mathrm{MP} / \mathrm{w}}$ of this study fall within a lower range (0.70 to 3.36). Furthermore, for 286 BSA a much stronger sorption of 2-naphthoic acids compared to 1-naphthoic acids was found, ${ }^{14}$ 287 whereas for muscle protein all naphthoic acids have similar partition coefficients. This indicates 288 steric effects for binding to BSA, but not for binding to muscle protein. As was observed with 289 BSA, sorption to muscle protein for ortho-substituted benzoic acids seems to be lower than for 290 other benzoic acids. For example, $\log K_{\mathrm{MP} / \mathrm{w}}$ for 3-chlorobenzoic acid, 4-chlorobenzoic acid, and 291 3,4-dichlorobenzoic acid is $0.72,0.72$, and 1.31, respectively, while binding of 2-chlorobenzoic 292 acid, 2,6-dichlorobenzoic acid, and 2,4,6-trimethylbenzoic acid was too weak to be measurable 293 (fraction bound $<20 \%, \log K_{\mathrm{MP} / \mathrm{w}}<0.6$ ). The dataset for muscle protein includes three pairs of 294 chemicals with the same non-ionic substructure, but with either a sulfonate or a carboxylate 295 group as charged functional group: 4-bromobenzenesulfonate and 4-bromobenzoic acid, 296 naphthalene-2-sulfonate and 2-naphthoic acid, and 1-pyrene sulfonate and 1-pyrenecarboxylic 297 acid. The difference between $\log K_{\mathrm{MP} / \mathrm{w}}$ measured for sulfonates and carboxylates is small $(\leq 0.1$ 298 log units), which is again similar to the observations with BSA. 


\section{Theoretical contribution of neutral species to determined $\log K_{\mathrm{MP} / \mathrm{w}}$}

300 As stated in the method section, all test chemicals were more than $97 \%$ present as ions in the

301 experiments. Hence, it is assumed that the measured $\log K_{\mathrm{MP} / \mathrm{w}}$ represent the partition coefficients

302 of the ionic species and that the contribution of the neutral species can be neglected. To verify

303 this assumption the following calculation was done. Using PP-LFERs $\log K_{\mathrm{MP} / \mathrm{w}}$ can be

304 calculated for the corresponding neutral species of the test chemicals (see also next section and

$305 \mathrm{SI}$ ). The calculated $\log K_{\mathrm{MP} / \mathrm{w}}$ of the neutral species (Table S8, SI) are on average $0.6 \log$ units

306 higher than the measured $\log K_{\mathrm{MP} / \mathrm{w}}$ of the ionic species. The highest positive difference was

307 calculated for 2-cyclohexylbenzoic acid (1.47 log units) and the highest negative difference for

308 coumafuryl ( $0.3 \log$ units). With the $\log K_{\mathrm{MP} / \mathrm{w}}$ of the neutral species and the $\mathrm{p} K_{\mathrm{a}}$ value of the

309 chemical and the $\mathrm{pH}$ value at which the partition coefficients were measured, the contribution of

310 the neutral species to the measured $\log K_{\mathrm{MP} / \mathrm{w}}$ can be calculated. A contribution of $\leq 7 \%$ was

311 calculated for all test chemicals except for only one chemical (Table S8, SI). Hence, the

312 influence of the neutral species on the measured $\log K_{\mathrm{MP} / \mathrm{w}}$ is estimated to be generally negligible.

313 The exception was dibenzylamine, for which $40 \%$ contribution of the neutral species was

314 calculated. The $\mathrm{p} K_{\mathrm{a}}$ value of dibenzylamine used for the calculation was 8.54 (predicted using

315 Calculator Plugins from Marvin 15.8.17.0, 2015, ChemAxon) and agrees with an experimental

$316 \mathrm{p} K_{\mathrm{a}}$ value reported in the literature (8.52). ${ }^{27}$ However, no experimentally determined PP-LFER

317 descriptors were available for dibenzylamine and the reliability of the calculation cannot be

318 further evaluated. As the major contribution $(60 \%)$ is from the ionic species, in the following

319 discussions we assume that the measured $\log K_{\mathrm{MP} / \mathrm{w}}$ for dibenzylamine is attributable to its ionic

320 species, bearing in mind that the value used might be subject to a relatively large error. 
321

322

323

324

325

326

327

328

329

330

331

332

333

334

335

336

337

338

339

340

341

342

343

344

\section{Polyparameter linear free energy relationships (PP-LFERs)}

For neutral organic chemicals a PP-LFER model for muscle protein-water partition coefficients based on equation 2 is already available from the literature (eq. 4 in Table 3 ). ${ }^{9}$

$$
\log K_{M P / w}=c+e E+s S+a A+b B+v V
$$

In eq. 2 the capital letters represent the substance properties and the small letters the corresponding system properties. $E$ is the excess molar refraction, $S$ is the polarizability/dipolarity parameter, $A$ represents the H-bond donor properties, $B$ the H-bond acceptor properties, and $V$ is the molar volume. This PP-LFER approach is applicable for neutral chemicals only.

Abraham et al. ${ }^{28,29}$ have proposed a PP-LFER equation that can be used for ionic chemicals as well (eq. 3).

$$
\log K_{M P / w}=c+e E_{i}+s S_{i}+a A_{i}+b B_{i}+v V_{i}+j^{+} J_{i}^{+}+j^{-} J_{i}^{-}
$$

Note that in this approach ionic chemicals do not only have specific descriptor values for $E, S, A$, $B$ and $V$ (denoted with subscript $i$ ), but also require two additional descriptors for their charge $\left(J_{i}^{+}\right.$and $\left.J_{i}^{-}\right)$. The flow chart in Figure S5 shows how the PP-LFER equation for the organic ions in this study was derived. Descriptors for the neutral species of all test chemicals $(E, S, A, B, V)$ were required for the calculation of the descriptors of the corresponding ionic species. If available, the experimentally determined descriptors of neutral species collected in the UFZLSER database ${ }^{30}$ were used. For many chemicals no experimental substance descriptors were found and the descriptors for such chemicals were predicted using the ABSOLV module from the ACD/Percepta software (2015 release). Using the empirical equations from Abraham et al. ${ }^{28,}$ ${ }^{31}$ and the descriptors of the neutral species, descriptors of the ionic species $\left(E_{i}, S_{i}, A_{i}, B_{i}, V_{i}, J_{i}^{+}\right.$, $\left.J_{i}^{-}\right)$were calculated. Because such equations are only available for phenols, carboxylic acids, pyridines, and amines, eleven chemicals had to be excluded from the calculation (e.g., sulfonates, 
345 coumarines, quaternary ammonium compounds). $K_{\mathrm{MP} / \mathrm{w}}$ data for 46 neutral chemicals from Endo

346 et al. ${ }^{9}$ were added for extension of the dataset.

347 Table 3. Regression equations derived for $\log K_{\mathrm{MP} / \mathrm{w}}\left[\mathrm{L}_{\mathrm{water}} / \mathrm{kg}_{\mathrm{MP}}\right]$, values in parentheses denote 348 standard errors.

\begin{tabular}{lccccccccccc}
\hline Eq. & $\boldsymbol{e}$ & $\boldsymbol{s}$ & $\boldsymbol{a}$ & $\boldsymbol{b}$ & $\boldsymbol{v}$ & $\boldsymbol{c}$ & $\boldsymbol{j}^{-}$ & $\boldsymbol{j}^{+}$ & $\boldsymbol{n}$ & $\boldsymbol{R}^{2}$ & RMSE \\
\hline \multirow{2}{*}{ eq. 4 } & 0.51 & -0.51 & 0.26 & -2.98 & 3.01 & -0.79 & - & - & 46 & 0.95 & 0.22 \\
& $(0.10)$ & $(0.17)$ & $(0.17)$ & $(0.24)$ & $(0.21)$ & $(0.25)$ & - & & & & \\
eq. 5 & 0.675 & -0.764 & -0.196 & -2.285 & 2.511 & -0.237 & 2.890 & -0.682 & 86 & 0.887 & 0.288 \\
\hline
\end{tabular}

${ }^{\text {a }}$ equation taken from Endo et al. ${ }^{9}$ calibrated with neutral chemicals only.

349 All chemicals (46 neutral, 34 anionic, 6 cationic, 86 in total) were used to derive all system

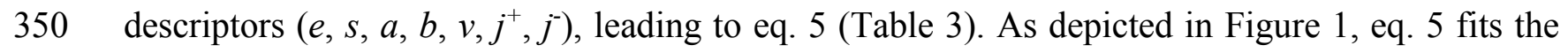

351 data well for all chemicals $(\operatorname{RMSE}=0.29)$. Eq. 5 calculates $\log K_{\mathrm{MP} / \mathrm{w}}$ of neutral chemicals

352 almost as well as eq. 4 (RMSE $=0.26$ for eq. 5 for neutral chemicals only, compared to RMSE $=$

3530.22 for eq. 4). Hence, eq. 5 may provide a predictive tool for partitioning of both neutral and

354 ionic chemicals to structural proteins. The good performance of eq. 5 is surprising, keeping in

355 mind that empirical formulas were used to calculate the descriptors of ionic species from the

356 descriptors of neutral species and that the descriptors of the neutral species themselves are also

357 predicted for many chemicals (23 out of 40 ionic chemicals). In the Supporting Information two

358 additional fits are presented (eqs. 6, 7 in Table S5). For the first fit the system descriptors $e, s, a$,

$359 b$, and $v$ were derived by using only neutral chemicals. These descriptors $(e, s, a, b, v)$ were then

360 set as fixed and $j^{+}$and $j^{-}$were calculated using the data for ions. The second fit demonstrates how

361 the fit changes if only ionic chemicals were used for the calculation of all system descriptors.

362 Both equations predict the data worse than eq. 5, with the RMSE being 0.50 and 0.36 for the first

363 and second fit, respectively. 
The data for $K_{\mathrm{MP} / \mathrm{w}}$ were also compared with logarithmic octanol-water partition coefficients of 365 the neutral species of the test chemicals ( $\log K_{\text {ow }}$ neutral). A correlation with $\log K_{\text {ow }}$ neutral also 366 fits the data worse $\left(\mathrm{RMSE}=0.41, R^{2}=0.53\right)$ than eq. 5 (Figure $\left.\mathrm{S} 6, \mathrm{SI}\right)$.

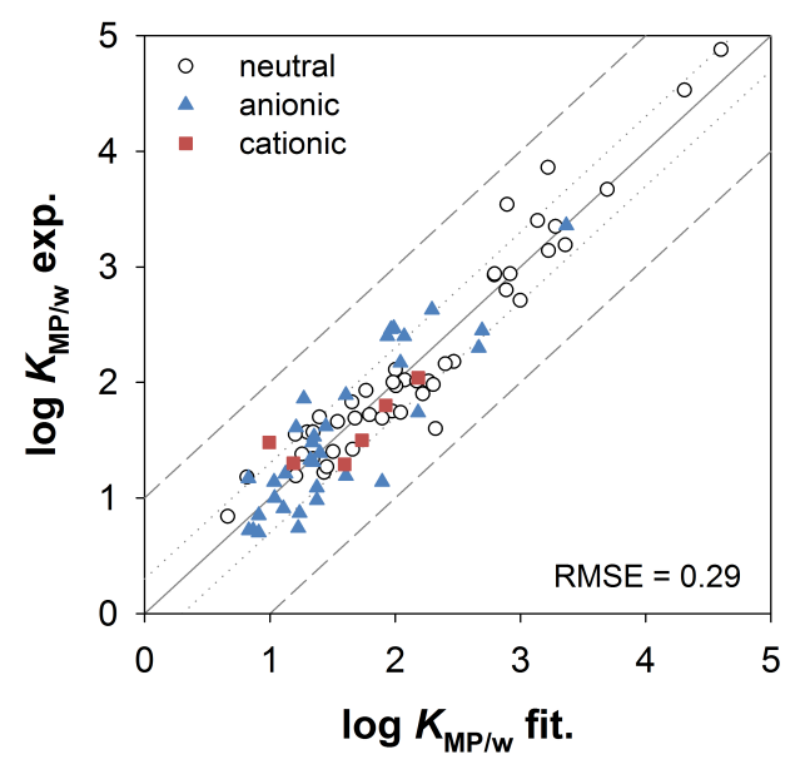

368 Figure 1. Comparison of PP-LFER fitted ( $\log K_{\mathrm{MP} / \mathrm{w}}$ fit.) using eq. 5 and experimentally 369 determined muscle protein-water partition coefficients (log $K_{\mathrm{MP} / \mathrm{w}}$ exp.). The solid line denotes 370 the 1:1 line, and dotted and dashed lines indicate a deviation of 0.3 and $1 \log$ unit, respectively.

\section{Comparison with serum albumin}

372 Figure 2 shows a comparison of experimental $\log K_{\mathrm{MP} / \mathrm{w}}$ and experimental BSA-water partition

373 coefficients $\left(\log K_{\mathrm{BSA} / \mathrm{w}}\right)$. For 31 anionic and 4 cationic chemicals of this work $\log K_{\mathrm{BSA} / \mathrm{w}}$ from

374 our previous study on BSA binding are available. ${ }^{14}$ Data for 39 neutral chemicals from Endo et

375 al. ${ }^{8,9}$ were included for comparison. While the data scatter considerably, some clear trends do 376 exist. For the neutral chemicals $\log K_{\mathrm{MP} / \mathrm{w}}$ is on average one $\log$ unit smaller than $\log K_{\mathrm{BSA} / \mathrm{w}}$. For 377 the anionic chemicals $\log K_{\mathrm{MP} / \mathrm{w}}$ is much smaller than $\log K_{\mathrm{BSA} / \mathrm{w}}$ by up to $3.7 \log$ units (for 2378 naphthaleneacetic acid and naphthalene-2-sulfonate). For the four cations $\log K_{\mathrm{MP} / \mathrm{w}}$ and $\log$ $379 K_{\mathrm{BSA} / \mathrm{w}}$ are similar. 


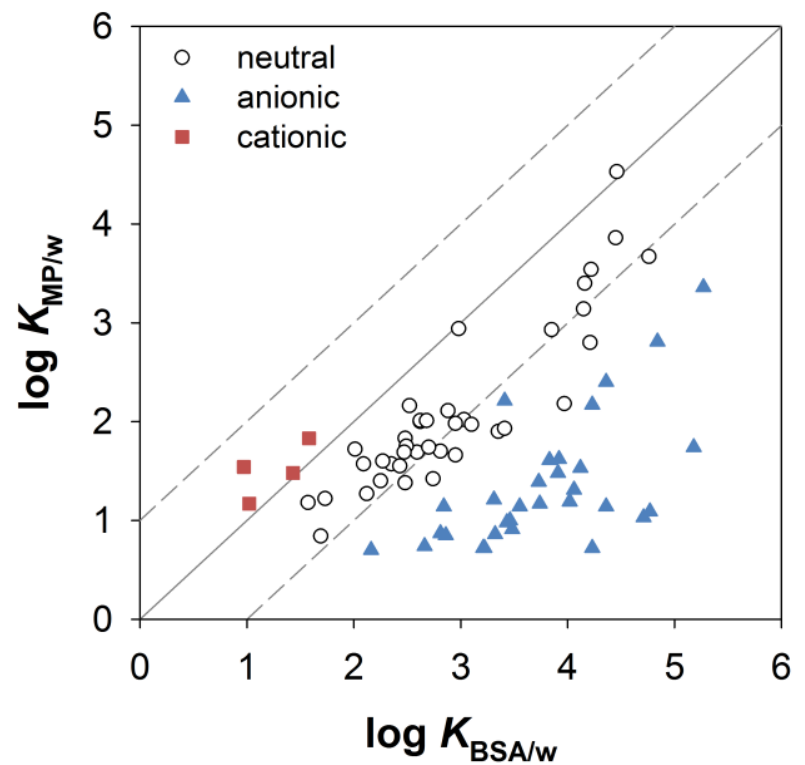

Figure 2. Comparison of experimentally determined muscle protein-water partition coefficients

$382\left(\log K_{\mathrm{MP} / \mathrm{w}}\right)$ and BSA-water partition coefficients $\left(\log K_{\mathrm{BSA} / \mathrm{w}}\right)$ for 39 neutral, 31 anionic and 4 383 cationic chemicals.

384 Combining the findings of this and the previous study, ${ }^{14}$ we shortly summarize here the 385 similarities and differences in sorption properties between BSA and muscle protein. First, 386 anionic chemicals sorb more strongly to BSA than to muscle protein, while cationic chemicals 387 seem to show similar partition coefficients to both proteins, as shown just above. Here, it should 388 be noted that a comparison of both proteins was only possible for four cationic chemicals (two 389 secondary and two tertiary amines) and could be specific for these chemicals. Second, a high 390 influence of the 3D molecular structure was found for sorption to BSA, while this was of minor 391 importance for muscle protein. Third, sorption to BSA is influenced by the concentration of 392 competing ions, whereas sorption to muscle protein is not. All in all, it is evident that sorption to 393 muscle protein and serum albumin can differ substantially (particularly for anionic and neutral 394 chemicals) and that for partitioning models (e.g., for the assessment of the bioaccumulation 
395 potential of chemicals) both proteins should be approached separately, instead of considering the

396 bulk protein fraction of an organism as one sorption phase.

\section{Implications for partitioning of IOCs in vivo}

398 As an application of the dataset obtained in this study, partition coefficients between muscle

399 tissue and plasma were estimated for different chemicals based on their partitioning to muscle

400 protein and serum albumin. In the literature ${ }^{32}$ it has been reported that in vivo measured muscle

401 tissue-plasma steady-state distribution ratios $\left(K_{\text {muscle/plasma }}\right)$ show the following trend: cationic

402 chemicals have the highest values for $K_{\text {muscle/plasma }}(0.5$ - 29), followed by neutral chemicals ( 0.4 -

403 6), while anionic chemicals show relatively small $K_{\text {muscle/plasma }}(<0.2)$. In Figure S7A selected

404 literature data are plotted for 11 neutral chemicals and 42 acids and bases that are predominantly

405 present in their ionic form ( $>95 \%)$ and have bound fractions of more than $20 \%$ in plasma.

406 Using a simple model (eq.8) equilibrium $K_{\text {muscle/plasma }}$ were estimated for all chemicals for 407 which experimental data for $K_{\mathrm{BSA} / \mathrm{w}}$ and $K_{\mathrm{MP} / \mathrm{w}}$ were available (4 cationic and 31 anionic 408 chemicals of this study and 39 neutral chemicals from Endo et al.$^{8,9}$ ).

$$
\mathrm{K}_{\text {muscle } / \text { plasma }}=\frac{f_{S A, \text { muscle }} \cdot K_{B S A / w}+f_{M P, \text { muscle }} \cdot K_{M P / w}+f_{w, \text { muscle }}}{f_{S A, p l a s m a} \cdot K_{B S A / w}+f_{\text {protein,plasma }} \cdot K_{M P / w}+f_{w, p l a s m a}}
$$

410 In the calculation it is assumed that the only relevant sorption phases in muscle tissue and 411 plasma are structural proteins, serum albumin, and water. The volume fractions of serum 412 albumin, muscle protein and water in muscle and plasma were calculated from physiological data 413 collected in refs ${ }^{15,16,33}$ and are denoted with $f_{\mathrm{SA}}, f_{\mathrm{MP}}$, and $f_{\mathrm{w}}$, respectively; $f_{\text {protein,plasma }}$ is the 414 fraction of other serum proteins. Serum proteins other than albumin are represented by muscle 415 protein, because partition coefficients to these proteins are not available for the test chemicals of 416 this study. The calculated values for $K_{\text {muscle/plasma }}$ are presented in Table S9 and Figure S7B. 417 Interestingly, these theoretical partition coefficients show the same trend and dimension as the 
418 literature data for $K_{\text {muscle/plasma. }}$. The highest values for $K_{\text {muscle/plasma }}$ were calculated for the four

419 cationic chemicals $(2.5$ - 4.3). Neutral chemicals generally show lower values than cations $(0.1$ -

$420 \quad 4.3)$ and for all anionic chemicals a very low $K_{\text {muscle/plasma was calculated }(\leq 0.4) \text {. Experimental }}$

$421 \log K_{\text {muscle/plasma }}$ for (S)-(-)-propranolol and verapamil are 0.63 and 0.54 , respectively, and agree

422 well with the calculated partition coefficients of 0.47 and 0.64 , respectively. While more data are

423 clearly required to assess partitioning of IOCs into biological tissues, the good prediction of the

424 trends for in vivo $K_{\text {muscle/plasma }}$ is encouraging, as it suggests that the in vitro partitioning data for

425 isolated serum albumin and muscle protein are relevant for the assessments of the in vivo

426 behavior of IOCs.

427 It should be noted that the calculation of $K_{\text {muscleplasma }}$ above is very simplified, because it 428 considers only serum albumin and muscle protein. Significant partitioning to phospholipids 429 would increase the sorptive capacity of both plasma and muscle tissue. Because muscle tissue 430 has more phospholipids than plasma, ${ }^{33} K_{\text {muscle/plasma }}$ would increase with increasing sorption to 431 phospholipids. Specific sorption to plasma proteins other than serum albumin would increase the 432 sorptive capacity of the plasma and thus decrease $K_{\text {muscle/plasma. }}$ If $\alpha_{1}$-acid glycoprotein binding is 433 significant, for example, a lower $K_{\text {muscle/plasma }}$ is expected for neutral and cationic chemicals. 434 Furthermore, the partition coefficients measured in this study represent a mixture of the different 435 structural proteins found in muscle tissue. For a future extension of the modeling approach 436 discussed above to other tissues than muscle tissue, partitioning behavior of organic ions towards 437 other types of structural protein (e.g., keratin and collagen) should also be evaluated.

\section{ASSOCIATED CONTENT}

439 Supporting Information. Further information on the test chemicals, preparation of muscle 440 protein, salt concentration and $\mathrm{pH}$ dependence of $\log K_{\mathrm{MP} / \mathrm{w}}$, PP-LFER modeling and predicted 
441 muscle tissue-plasma partition coefficients; 6 additional figures (including sorption isotherms for

442 selected chemicals) and 9 additional tables. This material is available free of charge via the

443 Internet at http://pubs.acs.org.

444 AUTHOR INFORMATION

445 Corresponding Author

$446 *$ Tel: ++81-6-6605-2763, E-mail: satoshi.endo@urban.eng.osaka-cu.ac.jp

\section{ACKNOWLEDGMENT}

448 We thank Trevor N. Brown for the collection of physiological data and Grit Weichert for help 449 in the preparation of muscle protein. Special thanks go to Andrea Pfennigsdorff for her 450 assistance in laboratory work. Satoshi Endo acknowledges the support by the MEXT/JST Tenure 451 Track Promotion Program.

452 REFERENCES

453 1. Endo, S.; Brown, T. N.; Goss, K.-U., General Model for Estimating Partition Coefficients 454 to Organisms and Their Tissues Using the Biological Compositions and Polyparameter Linear 455 Free Energy Relationships. Environ. Sci. Technol. 2013, 47, (12), 6630-6639.

456 2. van der Heijden, S. A.; Hermens, J. L. M.; Sinnige, T. L.; Mayer, P.; Gilbert, D.; Jonker, 457 M. T. O., Determining High-Quality Critical Body Residues for Multiple Species and Chemicals 458 by Applying Improved Experimental Design and Data Interpretation Concepts. Environ. Sci. 459 Technol. 2015, 49, (3), 1879-1887.

$460 \quad 3 . \quad$ Escher, B. I.; Cowan-Ellsberry, C. E.; Dyer, S.; Embry, M. R.; Erhardt, S.; Halder, M.; 461 Kwon, J.-H.; Johanning, K.; Oosterwijk, M. T. T.; Rutishauser, S.; Segner, H.; Nichols, J., 
462 Protein and Lipid Binding Parameters in Rainbow Trout (Oncorhynchus mykiss) Blood and 463 Liver Fractions to Extrapolate from an in Vitro Metabolic Degradation Assay to in Vivo 464 Bioaccumulation Potential of Hydrophobic Organic Chemicals. Chem. Res. Toxicol. 2011, 24, 465 (7), 1134-1143.

466 4. Poole, C. F.; Ariyasena, T. C.; Lenca, N., Estimation of the environmental properties of 467 compounds from chromatographic measurements and the solvation parameter model. J. 468 Chromatogr. A 2013, 1317, 85-104.

469 5. Endo, S.; Goss, K.-U., Applications of Polyparameter Linear Free Energy Relationships 470 in Environmental Chemistry. Environ. Sci. Technol. 2014, 48, (21), 12477-12491.

471 6. Geisler, A.; Endo, S.; Goss, K.-U., Partitioning of Organic Chemicals to Storage Lipids: 472 Elucidating the Dependence on Fatty Acid Composition and Temperature. Environ. Sci. Technol. $4732012,46,(17), 9519-9524$.

474 7. Endo, S.; Escher, B. I.; Goss, K. U., Capacities of Membrane Lipids to Accumulate 475 neutral Organic Chemicals. Environ. Sci. Technol. 2011, 45, 5912-5921.

476 8. Endo, S.; Goss, K. U., Serum Albumin Binding of Structurally Diverse Neutral Organic 477 Compounds: Data and Models Chem. Res. Toxicol. 2011, 24, (12), 2293-2301.

478 9. Endo, S.; Bauerfeind, J.; Goss, K.-U., Partitioning of Neutral Organic Compounds to 479 Structural Proteins. Environ. Sci. Technol. 2012, 46, (22), 12697-12703.

480 10. Armitage, J. M.; Arnot, J. A.; Wania, F.; Mackay, D., Development and evaluation of a 481 mechanistic bioconcentration model for ionogenic organic chemicals in fish. Environ. Toxicol. 482 Chem. 2013, 32, (1), 115-128. 
11. Peters Jr, T., All About Albumin. Academic Press: San Diego, 1995.

12. Kragh-Hansen, U., Molecular aspects of ligand binding to serum albumin. Pharmacol. 485 Rev. 1981, 33, (1), 17-53.

486 13. Kremer, J. M.; Wilting, J.; Janssen, L. H., Drug binding to human alpha-1-acid 487 glycoprotein in health and disease. Pharmacol. Rev. 1988, 40, (1), 1-47.

488 14. Henneberger, L.; Goss, K. U.; Endo, S., Equilibrium Sorption of Structurally Diverse 489 Organic Ions to Bovine Serum Albumin. Environ. Sci. Technol. 2016, 50, (10), 5119-26.

490 15. ICRP, Report of the Task Group on Reference Man. ICRP Publication 231975.

491 16. ICRP, 2002. Basic Anatomical and Physiological Data for Use in Radiological Protection 492 Reference Values. ICRP Publication 89. Ann. ICRP 32 (3-4).

493 17. Xing, B.; McGill, W. B.; Dudas, M. J., Sorption of benzene, toluene, and o-xylene by 494 collagen compared with non-protein organic sorbents. Can. J. Soil Sci. 1994, 74, (4), 465-469.

495 18. Hansen, S.; Selzer, D.; Schaefer, U. F.; Kasting, G. B., An extended database of keratin 496 binding. J. Pharm. Sci. 2011, 100, (5), 1712-1726.

497 19. Wang, L.; Chen, L.; Lian, G.; Han, L., Determination of partition and binding properties 498 of solutes to stratum corneum. Int. J. Pharm. 2010, 398, (1-2), 114-122.

499 20. Sudlow, G.; Birkett, D. J.; Wade, D. N., The Characterization of Two Specific Drug 500 Binding Sites on Human Serum Albumin. Mol. Pharmacol. 1975, 11, (6), 824-832.

501 21. Cheung, P. C. K.; Mehta, B. M., Eds. Handbook of Food Chemistry. Springer-Verlag: 502 Berlin Heidelberg, 2015; Vol. 1. 
22. Alberts, B., Molecular Biology of the Cell. Garland Pub.: 1989.

23. Oemisch, L.; Goss, K.-U.; Endo, S., Ion exchange membranes as novel passive sampling 505 material for organic ions: Application for the determination of freely dissolved concentrations. J.

506 Chromatogr. A 2014, 1370, 17-24.

507 24. Bischel, H. N.; MacManus-Spencer, L. A.; Zhang, C.; Luthy, R. G., Strong associations 508 of short-chain perfluoroalkyl acids with serum albumin and investigation of binding mechanisms. 509 Environ. Toxicol. Chem. 2011, 30, (11), 2423-2430.

510 25. Wilting, J.; van der Giesen, W. F.; Janssen, L. H.; Weideman, M. M.; Otagiri, M.; Perrin, 511 J. H., The effect of albumin conformation on the binding of warfarin to human serum albumin. 512 The dependence of the binding of warfarin to human serum albumin on the hydrogen, calcium, 513 and chloride ion concentrations as studied by circular dichroism, fluorescence, and equilibrium 514 dialysis. J. Biol. Chem. 1980, 255, (7), 3032-3037.

515 26. Honoré, B.; Brodersen, R., Detection of carrier heterogeneity by rate of ligand dialysis: 516 Medium-chain fatty acid interaction with human serum albumin and competition with chloride. 517 Anal. Biochem. 1988, 171, (1), 55-66.

518 27. Christensen, J. J.; Izatt, R. M.; Wrathall, D. P.; Hansen, L. D., Thermodynamics of proton 519 ionization in dilute aqueous solution. Part XI. pK, $\Delta \mathrm{H}^{\circ}$, and $\Delta \mathrm{S}^{\circ}$ values for proton ionization 520 from protonated amines at $25^{\circ}$. J. Chem. Soc. A $1969,1212-1223$.

521 28. Abraham, M. H.; Acree, W. E., Equations for the Transfer of Neutral Molecules and 522 Ionic Species from Water to Organic phases. J. Org. Chem. 2010, 75, (4), 1006-1015. 
523 29. Abraham, M. H.; Zhao, Y. H., Determination of Solvation Descriptors for Ionic Species:

524 Hydrogen Bond Acidity and Basicity. J. Org. Chem. 2004, 69, (14), 4677-4685.

525 30. Endo, S.; Watanabe, N.; Ulrich, N.; Bronner, G.; Goss, K.-U., UFZ-LSER database v 2.1 526 [Internet]. In Helmholtz Centre for Environmental Research-UFZ: Leipzig, Germany, 2015 ; Vol. $527 \quad \mathrm{v} 2.1$.

528 31. Abraham, M. H., The permeation of neutral molecules, ions, and ionic species through 529 membranes: Brain permeation as an example. J. Pharm. Sci. 2011, 100, (5), 1690-1701.

530 32. Yun, Y. E.; Edginton, A. N., Correlation-based prediction of tissue-to-plasma partition 531 coefficients using readily available input parameters. Xenobiotica 2013, 43, (10), 839-852.

532 33. White, D. A., The phospholipid composition of mammalian tissues. In Form and function 533 of phospholipids, Ansell, G. B.; Hawthorne, J. N.; Dawson, R. M. C., Eds. Elsevier Scientific 534 Publishing Company: Amsterdam, London, New York, 1973.

535

536 


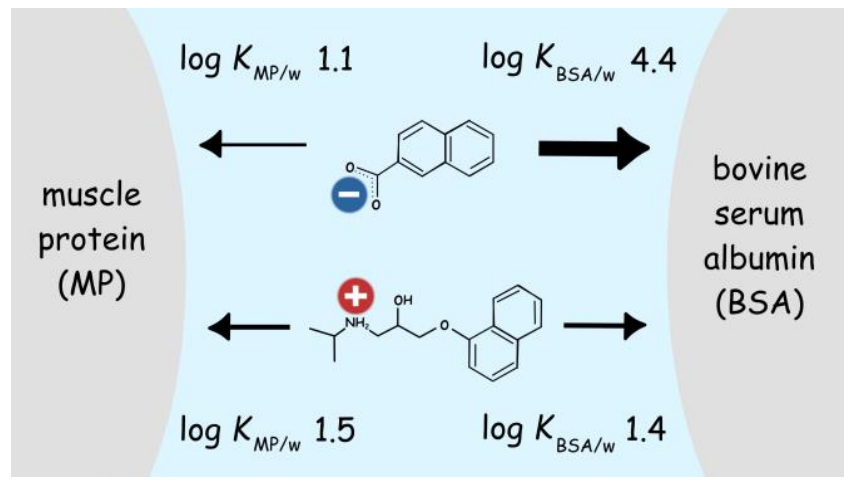

